\title{
Christian Discernment of Divine Revelation: Benedict XVI and the International Theological Commission on the Dark Passages of the Old Testament
}

\author{
Discernimiento cristiano de la revelación divina. \\ Los «pasajes oscuros» del Antiguo Testamento según \\ Benedicto XVI y la Comisión Teológica Internacional
}

Matthew Ramage, Ph.D.

Benedictine College

Atchison, Ks. EE.UU.

mramage@benedictine.edu

Abstract: In its recent document God the Trinity and the Unity of Humanity, the International Theological Commission offers principles to reconcile the many Old Testament texts in which God ostensibly acts against his own nature by commanding deeds such as the slaughter of men, women, and children. This piece frames discussion of so-called «dark passages» in light of three hermeneutical keys: the divine pedagogy, the discernment of authorial assertions, and the spiritual sense. In particular, these principles will be applied to Psalm 137, one of the most beautiful and yet disturbing texts of the Old Testament.

Keywords: Bible, Hermeneutics, Dark Passages.
Resumen: En su reciente documento Dios Trinidad, unidad de los hombres, la Comisión Teológica Internacional ofrece principios para reconciliar los muchos textos del Antiguo Testamento en los que Dios actúa ostensiblemente contra su propia naturaleza, al ordenar acciones como la masacre de hombres, mujeres y niños. Este trabajo enmarca la discusión de los llamados «pasajes oscuros» a la luz de tres claves hermenéuticas: la pedagogía divina, el discernimiento de las afirmaciones del autor, y el sentido espiritual. En particular, estos principios se aplicarán al Salmo 137, uno de los textos más bellos y, sin embargo, inquietantes, del Antiguo Testamento.

Palabras clave: Biblia, Hermenéutica, Pasajes oscuros. 


\section{VIOLENCE Is CONTRARY TO GOD's NATURE}

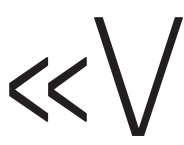
iolence is incompatible with the nature of God». In his $2006 \mathrm{Re}-$ gensburg Address, Pope Benedict XVI penned this line as part of his ongoing effort to disentangle theology from ideologies which «might even lead to the image of a capricious God, who is not even bound to truth and goodness» ${ }^{1}$. Although Benedict had Islam in his sights in making this particular point, the same warning equally applies to Christian theology and Scripture. In its recent document God the Trinity and the Unity of Humanity, the International Theological Commission (ITC) offers principles to reconcile the many Old Testament texts in which God ostensibly acts against his own nature by commanding deeds such as the slaughter of men, women, and children ${ }^{2}$. Within the constraints of this short note, one can have no pretense of offering an exhaustive defense of the many passages in the Bible which appear to contradict the words or our emeritus pontiff ${ }^{3}$. This piece frames discussion of the Bible's so-called «dark passages» in light of three hermeneutical keys: the divine pedagogy, the discernment of authorial assertions, and the spiritual sense. These principles will be applied to Psalm 137, one of the most beautiful and yet disturbing texts of the Old Testament.

The very notion that commanding violence is contrary to God's nature itself remains an area of debate in Catholic theology. There are good grounds for this dispute, as no less an authority than Thomas Aquinas sought to justify violent divine actions in the Old Testament on the basis of original sin. On account of this, all humans deserve the punishment of death, and thus «by the command of God, death can be inflicted on any man, guilty or innocent, without any injustice whatever» ${ }^{4}$. Likewise for Augustine, those who think

${ }^{1}$ BENEDICT XVI, Address at the University of Regensburg «Faith, Reason and the University: Memories and Reflections» (September 12, 2006).

${ }^{2}$ In particular, the document recalls the following examples: the Flood (Gen 6); the destruction of Sodom and Gomorrah (Gen 19); the death of the firstborn in Egypt and the annihilation of Egypt's army (Ex 7-13); the order to exterminate entire armies and cities during the conquest (Num 21:1-13; Josh 6:21; 8:22-25; 1 Sam 15:3); human sacrifices (Lev 20:2-5; 2 Kings 16:3; 21:6). ITC, God the Trinity and the Unity of Humanity, 26.

${ }^{3}$ For a more thorough attempt to develop such a hermeneutic, see my book Dark Passages of the Bible: Engaging Scripture with Benedict XVI and Thomas Aquinas, Washington, DC: Catholic University of America Press, 2013.

4 Thomas Aquinas, Summa Theologiae, I-II, q. 94, a. 5 ad 2; cfr. I-II, q. 100, a. 8, II-II, q. 154, a. 2 ad 2. Aquinas's approach to the subject in De malo is very similar. See ibid., q. 3, a. 1, ad 17; q. 15 , a. 1 ad 8. 
that God is cruel for killing people fail to realize the gravity of sin and the punishment it deserves 5 . While both of the above authors are saints and doctors of the Church, their explanations of violence in the Old Testament leave many Christians today unsatisfied. Benedict XVI and the ITC respond to this dissatisfaction not by ignoring the criticisms of skeptics but rather beginning with the admission that the latter are justified in seeing the Old Testament's dark passages as problematic from a certain point of view.

\section{The Divine Pedagogy}

What explanation, then, does the Catholic have to offer a skeptic or a disconcerted Christian who has encountered such violent passages? First, Christians must admit that the Bible does in fact portray God performing violent deeds and commanding violence. Indeed, the ITC recognizes the presence of «tensions, conflicts, even violent excesses» in the history of Israel as recorded in the Old Testament ${ }^{6}$. Second, it is important to follow Benedict in acknowledging the incompatibility of violence with the nature of God such as we understand it through reason. Third, the principal key according to the ITC is that the Christian must interpret the entire Old Testament in light of its gradual progression towards Jesus Christ. The ITC describes the Old Testament's redaction in terms of an evolutionary dynamic (dinamica evolutiva) wherein the faith of ancient Israel was gradually purified through a reconfiguration of memory (riconfigurazione della memoria). The ITC argues that it is from the retrospective vantage point of the fullness of faith that the entire antecedent process of divine revelation ought to be evaluated ${ }^{7}$.

\footnotetext{
${ }^{5}$ «One should not at all think it a horrible cruelty that Joshua did not leave anyone alive in those cities that fell to him, for God himself had ordered this. However, whoever for this reason thinks that God himself must be cruel... judges as perversely about the works of God as he does about the sins of human beings. Such people do not know what each person ought to suffer». AugusTINE, Questions on Foshua, 16. Translation taken from vol. 4 of Ancient Christian Commentary on Scripture: Old Testament, Downers Grove, Ill: InterVarsity Press, 2005, 67; cfr. Josh 11:14.

${ }^{6}$ ITC, God the Trinity and the Unity of Humanity, 24. Since there currently exists no official English text of this work in English, translations cited in this piece are mine.

${ }^{7}$ Ibid., 27. While the ITC speaks here of developments within the Bible in evolutionary terms, John Henry Newman sees good reason not to describe the phenomenon precisely in this way. See his Essay on the Development of Christian Doctrine, Notre Dame, IN: University of Notre Dame Press, 1989, 172, where he argues for the distinction between development and evolution based on the Church's profession that the substance of the faith has not changed over time, as would be implied if one adopted the evolutionary paradigm of species change. In this same paragraph
} 
Benedict XVI makes precisely this point when he states, «Anyone who wishes to understand the biblical belief in God must follow its historical development from its origins with the patriarchs of Israel right up to the last books of the New Testament $»^{8}$. Christians believe that the fullness of truth is revealed in the person, teaching, and ministry of Jesus Christ. Indeed, Benedict goes so far as to say that problematic passages in the Old Testament are «valid insofar as they are part of the history leading up to Christ» ${ }^{9}$. The pontiff's 2010 exhortation Verbum Domini speaks similarly. In a section of the document entitled «Dark Passages of the Bible», Benedict teaches that instances of violence and immorality in the Bible can be adequately addressed only if Catholics take seriously the fact that «God's plan is manifested progressively and it is accomplished slowly, in successive stages and despite human resistance» ${ }^{10}$. In a similar vein to the ITC, Benedict emphasizes that «revelation is suited to the cultural and moral level of distant times», and it is for this reason that it narrates certain events without denouncing their immorality in the way that Christians rightly do today. In an interview Benedict put the matter

the ITC draws a parallel between the progressiveness of divine revelation and development of doctrine within the Church. Here it is Newman again who sees such an analogy when he writes, «The prophetic Revelation is, in matter of fact... a process of development: the earlier prophecies are pregnant texts out of which the succeeding announcements grow; they are types. It is not that first one truth is told, then another; but the whole truth or large portions of it are told at once, yet only in their rudiments, or in miniature, and they are expanded and finished in their parts, as the course of revelation proceeds». Ibid., 64. Newman has the correct intuition that there exists an underlying «Idea» behind revelation itself which was clarified gradually over time as Israel grew in her ability to apprehend the Lord's teaching. Indeed right after the passage just cited he says, «The whole Bible, not its prophetical portions only, is written on the principle of development», and «It is certain that developments of Revelation proceeded all through the Old Dispensation down to the very end of our Lord's ministry». Ibid., 65, 67-68.

${ }^{8}$ BenEdICT XVI, Introduction to Christianity, San Francisco: Ignatius Press, 2004, 116. Note that I have for the most part opted for the convention of referring to the one man Ratzinger/Benedict as «Benedict» throughout this article even in writings antedating his pontificate.

9 Benedict XVI, Dogma and Preaching: Applying Christian Doctrine to Daily Life, San Francisco: Ignatius Press, 2011, 200.

10 Benedict XVI, Verbum Domini, 42 (emphasis Benedict's). As Benedict put it in a homily on Genesis' creation account, «The Bible is thus the story of God's struggle with human beings to make himself understandable to them over the course of time; but it is also the story of their struggle to seize hold of God over the course of time... The whole Old Testament is a journeying with the Word of God. Only in the process of this journeying was the Bible's real way of declaring itself formed, step by step... For the Christian the Old Testament represents, in its totality, an advance toward Christ; only when it attains to him does its real meaning, which was gradually hinted at, become clear». In the Beginning: A Catholic Understanding of the Story of Creation and the Fall, trans. Boniface Ramsey, Grand Rapids: Eerdmans, 1995, 10-11. 
bluntly: «It follows straightaway that neither the criterion of inspiration nor that of infallibility can be applied mechanically. It is quite impossible to pick out one single sentence [of the Bible] and say, right, you find this sentence in God's great book, so it must simply be true in itself $>^{11}$.

As the Second Vatican Council authoritatively taught, Catholics continue to profess that the Bible is the inspired and inerrant word of God ${ }^{12}$. Thus if the above statements from our emeritus pope scandalize faithful Christians, then this only indicates that some believers have a very restrictive conception of biblical inerrancy in which the Old Testament is taken for a video account or transcript of what God said and did in times of old. To be sure, one need not nor should not deny the doctrines of biblical inspiration and inerrancy. Yet Christians who continue to maintain these doctrines in the face of compelling contradictory evidence must also recognize that the people who penned the Old Testament were not privy to the fullness of divine revelation and the $\mathrm{Ca}$ tholic tradition. Eventually Christians would discover that our omnipotent and omnibenevolent God allows evil and cannot directly cause it, and thus we now distinguish between God's active will and his permissive will. However, this distinction was not made by the authors of the Old Testament for the simple reason that it had not yet been revealed to them ${ }^{13}$.

One might well ask why God did not reveal this important distinction earlier or why the Old Testament's conception of God should be imperfect. To borrow an ancient expression reiterated by the Catechism, the cause for this dynamic lies in the wisdom of the divine pedagogy by which God revealed himself to his people gradually and successively over the ages ${ }^{14}$. Like any pedagogue, God had to work with stubborn and unintelligent pupils in whom he met constant resistance. Naturally, these humans were not going to perceive God's will perfectly from the outset of his divine revelation but rather grow in its perception over time. All the same, God accommodated himself to man's human weaknesses and ennobled feeble humans in such a way that they truly became bearers of his word and not merely passive instruments. The imperfections we see in the Old Testament are therefore not a scar of which Chris-

${ }^{11}$ Benedict XVI, God and the World, San Francisco: Ignatius Press, 2003, 153.

12 Second Vatican Council, Dei Verbum, 11.

${ }^{13}$ For a discussion of this distinction and its importance for reconciling Old Testament texts, see my Dark Passages of the Bible, 188-200.

${ }^{14}$ Cfr. Catechism of the Catholic Church, 53. 
tians should be ashamed, but rather evidence of God's gracious will to condescend and patiently lead a human people into communion with himself in a gradual way consonant with man's rational nature. Problematic passages within Scripture are among the clearest of evidence that God's grace does not eliminate human nature but builds upon it and perfects it.

Skeptics will most likely remain unconvinced by the above explanation for a couple of reasons. On the one hand, the above abbreviated summary covers only one key distinction needed to account for the Bible's dark passages. More importantly, however, to accept the divine pedagogy hermeneutic elaborated here is already to have accepted something prior to it: namely, the existence of God and faith in Jesus Christ. Seeing Old Testament passages in light of their progression towards Jesus is only going to satisfy those of us who already believe that Jesus is God in the flesh. When it comes to presenting an explanation of the Bible's «dark passages» to non-believers, we must follow the path laid out by Thomas Aquinas. The only thing a Christian can do for those who deny his principles is to answer objections so that the skeptic might see what a reasonable way to deal with dark biblical passages would look like if faith in Christ and his revealed word is granted ${ }^{15}$.

\section{DisCERNING THE SACRED AUTHOR's ASSERTION}

The Catholic who wishes to offer a compelling account for the presence of «dark passages» in the Bible cannot remain at the level of abstraction but must apply his principles to concrete biblical texts. Here we will consider another principle in light of a short text which is at once one of the most profound as well as troubling passages of the Bible. Psalm 137 is a hymn whose context is clearly exilic, meaning that it was written after the Jewish people had been carted off into Babylon in 586 B.C. Before exegeting, the poem should be read in its entirety:

By the waters of Babylon, there we sat down and wept, when we remembered Zion.

On the willows there we hung up our lyres.

${ }^{15}$ Cfr. Thomas Aquinas, Summa Theologiae, I, q. 1, a. 8. 
For there our captors

required of us songs,

and our tormentors, mirth, saying,

«Sing us one of the songs of Zion!».

How shall we sing the LORD's song

in a foreign land?

If I forget you, O Jerusalem,

let my right hand wither!

Let my tongue cleave to the roof of my mouth,

if I do not remember you,

if I do not set Jerusalem

above my highest joy!

Remember, O LORD, against the E'domites

the day of Jerusalem,

how they said, «Rase it, rase it!

Down to its foundations!».

O daughter of Babylon, you devastator!

Happy shall he be who requites you

with what you have done to us!

Happy shall he be who takes your little ones

and dashes them against the rock!

The problem posed by this text is obvious to anyone who reads it through to the end. The plain sense of the last pair of verses is a proclamation of blessing upon the man who has killed his captors' little children. This is one of those points at which skeptics somewhat understandably accuse believers of worshiping a hateful, genocidal, and bloodthirsty god ${ }^{16}$. Even the great apologist C. S. Lewis, in his Reflections on the Psalms, describes Psalm 137's concluding outburst as «devilish» ${ }^{17}$. According to Lewis, the harboring of animosity is at once «profoundly natural» but also «profoundly wrong» ${ }^{18}$. Does this mean that it should be in the Bible or that it constitutes an error on God's part?

\footnotetext{
${ }^{16}$ See, for example, the array of adjectives predicated of God by atheist R. DAWKINS in The God Delusion, Boston: Houghton Mifflin, 2006, 31 and the criticisms of Ch. Hitchens in God is Not Great: How Religion Poisons Everything, New York: Twelve, 2007, 106.

${ }^{17}$ LEWIs, C. S., Reflections on the Psalms, London: Harvest Books, 1964, 20.

${ }^{18}$ Ibid., 26.
} 
Though Psalm 137 does not have God directly pronouncing this troublesome curse, its problematic presence cannot be skirted merely by pointing out that the human author is the one saying these hateful things rather than God. The Bible is God's word in human words, and so whatever Scripture's human authors assert is also asserted by the Holy Spirit. Catholicism teaches that lying, falsehood, and hatred are incompatible with the nature of God. Therefore if the human author of Psalm 137 asserts an error, this is tantamount to admitting that the Holy Spirit has asserted an error.

For a Catholic, the question ultimately revolves around ascertaining what precisely the human author of Psalm 137 was asserting. This assertion refers to the primary message an author wishes to teach or communicate. The Catholic must first be clear that Psalm 137 is not asserting that celebration is in order when the children of our enemies are killed. Now the skeptic might respond to this by arguing that precluding this sense amounts to pre-determining that the biblical text cannot be teaching something known to be incompatible with the nature of God. The Catholic, however, should to a certain extent agree with his interlocutor here. The Christian's prior commitment to Jesus and to the truth of the Bible does a priori preclude the possibility that God's revealed word asserts error. Thus if we come to know a truth through reason (e.g. that violence is incompatible with the nature of God), then our biblical interpretation must be rethought in this light. As Aquinas says, one should be ready to abandon an explanation if it is proved to be false, lest the Bible be exposed to the ridicule of unbelievers and obstacles be placed to their believing ${ }^{19}$. As said above, this does not mean that the Catholic position is irrational or indefensible. It simply means that Catholics cannot expect nonbelievers to accept our particular interpretation of a text like Psalm 137 if said person has not first accepted the existence of God, the incarnation of Christ, and the Bible as his revealed word expressed in human words. What we can do is offer a reasoned explanation for the presence of thorny texts in such a way that one could see how it would be illuminating if faith in Christ is granted.

Up to this point we have merely been discussing what Psalm 137 does not intend to teach, but it is also necessary to offer a positive statement of what the sacred author intended to assert. In the present psalm as in any biblical

19 Thomas Aquinas, Summa Theologiae, I, q. 68, a. 1. 
text, an author might wish to make multiple points. In this case, two related purposes of the psalm may be discerned when read in light of the whole. On the one hand, it is intended to express hope for liberation and confidence in God's covenant faithfulness ${ }^{20}$. Thus the beautiful words in which the psalmist reminds the people of God's promise: «If I forget you, O Jerusalem, let my right hand wither!» God has bound himself to Israel in covenant. He cannot go back on his promise to remember his people.

Though expressive of hope, Psalm 137 is at the same time a national hymn of sorrow ${ }^{21}$. As the text relates, Israelites cast into Babylonian captivity wept bitterly as they were mocked by their captors who asked them to sing songs of their native land which had just been destroyed. Accordingly, in this text the psalmist intends to pour out his nation's anguish to God over the loss of land, family, and cult. His aim is not to assert a universal truth claim about children and the evil that ought to be revenged upon them. One cannot simply isolate the last pair of verses from the context and message of the whole. Rather, the central thrust of Psalm 137 is its cry of longing for God and for God's good gifts to be restored.

\section{The Spiritual Sense}

To be sure, the frightful side of human nature shines through in Psalm 137, but for the Christian this makes the text all the more real and meaningful. In this way it becomes a prayer which we today (with proper caution and making due distinctions) can each take up in our own lives. This is the spiritual sense of the text, an application to the believer's own life circumstances of what was learned through the experience of God's people in ages past. Christians today find in our own hearts the same emotions of despair and hope, hatred and love that God's people of old experienced. The psalm teaches us that we should not try to hide our deepest and darkest thoughts from God. Rather the psalms teach us to get these out in the open so that God can help us live our sorrows in him and eventually heal our brokenness.

A final dimension of Psalm 137's spiritual sense is something that was picked up on by Christianity already in its first centuries of reflection upon the

${ }^{20}$ Benedict XVI draws out this dimension of the text in his general audience meditation on Psalm 137 (November 30, 2005), 1-2.

${ }^{21}$ Ibid., 1. 
text. I refer here to the beautiful and practical exegesis of Origen in his important treatise Against Celsus. Following the familiar lines of patristic-medieval thought, he comments:

The just give up to destruction all their enemies, which are their vices, so that they do not spare even the children, that is, the early beginnings and promptings of evil. In this sense also we understand the language of Psalm 137... For, «the little ones of Babylon» (which signifies confusion) are those troublesome sinful thoughts that arise in the soul, and he who subdues them by striking, as it were, their heads against the firm and solid strength of reason and truth, is the man who «dashes the little ones against the stones» and he is therefore truly blessed ${ }^{22}$.

For Origen, there is no question as to the psalm's meaning: the «little ones» who are to be slain are not human children but rather «the early beginnings and promptings of evil». Origen justifies the psalmist's words by appealing to the etymology of the word Babylon, which is related to the word «confusion». According to Origen, nascent vices are called «the little ones of Babylon» because they arise in the form of troubling thoughts that confuse one's soul. The message of the psalm is that we should put an end to our evil behavior at its outset -when it is still in its infancy, so to speak- lest it eventually develop into an unbreakable vice.

Origen's interpretation squares well with the experience of anyone who has ever struggled to overcome sinful inclinations, and yet it does not sufficiently account for the presence of this text in the Bible on its own. Anyone who thinks that jumping to this spiritual sense of Psalm 137 does justice to its violent outburst of vengeance needs to ask whether Origen's exegesis effectively captures the literal sense of Psalm 137 . Yes, the Catholic should happily recognize the spiritual sense of the text, but was the psalmist really thinking about crushing his vices when he composed this psalm? To this author it seems disingenuous to reply in the negative, yet notwithstanding what the author thought, the doctrine of inerrancy concerns not this but rather what he intended to assert or teach ${ }^{23}$. While some refuse to admit that the psalmist actually

${ }^{22}$ Origen, Against Celsus, 7.22.

${ }^{23}$ Cfr. Dei Verbum, 11. As Germain Grisez has noted in a helpful essay, it is a great mistake to read the statement «everything asserted by the inspired authors or sacred writers must be held to be asserted by the Holy Spirit» as saying that «everything in Scripture is asserted by the Holy 
entertained the hateful thoughts he appears to entertain, the principles offered above are an attempt to seek truth in the text while admitting the presence of troubling statements which skeptics rightly take to be at odds with the nature of God.

\section{CONCLUSION}

Regardless of whether the above attempt to reconcile Psalm 137 is sound, all believers who reflect upon their vices can find great wisdom for life in Origen's exhortation to blot out nascent defects in our lives before they grow up and develop into full-fledged vices. This is precisely the sort of exegesis that makes a difference in our lives, and for the Catholic it represents the raison d'etre of the Bible. But he who wishes to appreciate Scripture fully must pay careful attention to both its spiritual and literal senses. The honest believer must beware of whitewashing difficult biblical texts by jumping to their spiritual sense without seriously taking into account the challenges these texts present on the literal level.

It is important to acknowledge and reiterate that ascertaining a biblical text's intention is not always an easy task. Catholics must respectfully disagree with some of our Protestant brethren who believe that the Bible's meaning is perspicuous. Exegesis requires great deal of skill, patience, and prayer. Above all, it requires us to recognize that the many troublesome passages of the Old Testament ultimately only make sense insofar as they are seen as part of a progressive revelation by which God gradually prepared his people for the coming of Christ. On the same token, biblical exegesis requires a degree of intellectual humility that skeptics and believers alike sometimes lack. Especially

Spirit». He elaborates, «Scripture contains not only many sentences expressing no proposition, but many sentences that express propositions not asserted by their human authors». GRISEZ, «The Inspiration and Inerrancy of Scripture», in St. Paul Center for Biblical Theology, For the Sake of Our Salvation: The Truth and Humility of God's Word, Steubenville, OH: Emmaus Road Publishing, 2010, 186. B. HARRISON, O.S., makes a similar clarification in which he demonstrates that Dei Verbum understands the word teach (docere) as referring to those things which are truly affirmed (asseruntur) in Scripture. HARRISON, «Does Vatican Council II Allow for Errors in Sacred Scripture?», Divinitas, LII, no. 3 (2009) 279-304. In contrast with Grisez, Harrison argues that the key distinction to maintain is not between «affirmations» or «teachings» on the one hand and «statements» on the other but rather between what is formally asserted (and cannot contain error) and what is merely «used» (and which can be materially erroneous) by the sacred writers in view of making these assertions. 
in today's world where so much of our information comes in short bursts of data via social media outlets, it is very common to find people assuming that if they do not understand a claim at first glance or if its meaning is not readily apparent to them, then it is not true. When the Catholic asks for the chance to clarify or make further distinctions, he is often accused of backpedaling, covering his tracks, or obfuscating the ostensible meaning of the text he is trying to defend.

When engaging in discussions like the present one, it is appropriate to recall C. S. Lewis' words in his book Miracles. Explaining Christianity to someone who thinks that the faith should be easy and simple is much like trying to explain quantum physics to someone who conceives of atoms as tiny little balls which comprise everything in the material universe. At every turn we have to multiply distinctions and rule out false analogies proffered by our interlocutors ${ }^{24}$. It sounds like backtracking, and sometimes it does represent a change in course with respect to previous explanations. But this precision is indispensable if we are to offer a reasonably adequate account of such immense and profound mysteries as we find in Sacred Scripture.

${ }^{24}$ LewIS, C. S., Miracles: A Preliminary Study, New York: Macmillan, 1978, especially 134-137. 


\section{Bibliography}

BENEDICT XVI, Address at the University of Regensburg «Faith, Reason and the University: Memories and Reflections» (September 12, 2006).

BenEDICT XVI, Dogma and Preaching: Applying Christian Doctrine to Daily Life, San Francisco: Ignatius Press, 2011, 200.

Benedict XVI, God and the World, San Francisco: Ignatius Press, 2003, 153. Benedict XVI, Introduction to Christianity, San Francisco: Ignatius Press, 2004, 116.

BENEDICT XVI, In the Beginning: A Catbolic Understanding of the Story of Creation and the Fall, trans. Boniface Ramsey, Grand Rapids: Eerdmans, 1995, $10-11$.

BENEDICT XVI, Verbum Domini, 42 (emphasis Benedict's).

LEWIS, C. S., Reflections on the Psalms, London: Harvest Books, 1964, 20.

LewIS, C. S., Miracles: A Preliminary Study, New York: Macmillan, 1978, especially $134-137$. 